NOTE

\title{
Shifting feeding behaviour of deep-sea buccinid gastropods at natural and simulated food falls
}

\author{
J. Aguzzi ${ }^{1, *}$, A. J. Jamieson ${ }^{2}$, T. Fujii ${ }^{2}$, V. Sbragaglia ${ }^{1}$, C. Costa $^{3}$, P. Menesatti ${ }^{3}$, \\ Y. Fujiwara ${ }^{4}$
}

\author{
${ }^{1}$ Marine Science Institute (ICM-CSIC), Paseo Maritímo de la Barceloneta, 37-49, 08003 Barcelona, Spain \\ ${ }^{2}$ Oceanlab, Institute of Biological and Environmental Science, University of Aberdeen, Main Street, Newburgh, \\ Aberdeenshire AB41 6AA, UK \\ ${ }^{3}$ Agricultural Engineering Research Unit of the Agriculture Research Council (CRA-ING), Via della Pascolare 16, \\ 00015 Monterotondo Scalo (Roma), Italy \\ ${ }^{4}$ Japan Agency for Marine-Earth Science and Technology (JAMSTEC), 2-15 Natsushima-Cho, Yokosuka, \\ Kanagawa 237-0061, Japan
}

\begin{abstract}
The deep sea is a low food input envionment, hence large food falls from the surface waters are important in suppor ting a wealth of scavenging deep-sea fauna. The pr obability of observing such events is ver y low, due to their unpr edictable and short-lived nature. The video system of a cabled obser vatory installed within a cold seep clam field in Sagami Bay (1100 m depth; Central Japan) recorded a rare event. We observed a fish dying directly in front of the camera and being immediately perceived and preyed upon by Buccinum yoroianum (Neogastropoda: Buccinidae), while still alive. Up to 76 large snails responded to the fish and consumed the carcass within $\sim 8 \mathrm{~h}$, with no inter vention by decapod crustaceans. There was only small participation of eelpouts (Zoarcidae). For comparison, we report on supplementary findings from a different area and depth of the Pacific Ocean. These obser vations were recorded by a baited camera lander which simulated a food fall. W ithin $6 \mathrm{~h}$, the buccinid Tacita zenkevitchi aggregated on the bait, competing with fishes. These observations confirm that deep-sea buccinids can shift their feeding behaviour between active pr edation and scavenging. Our perception, however, seems conditioned by the observational methodology we use: buccinids may appear as scavengers when using photography (e.g. by baited landers) pr oducing single snapshots in time, or as pr edators when observed in a natural setting and video-taped continuously with a cabled observatory.
\end{abstract}

KEY WORDS: Buccinum yoroianum - Tacita zenkevitchi · Zoarcids · Cabled observatories · Landers $\cdot$ Baited cameras $\cdot$ Scavenging behaviour $\cdot$ Natural food falls

\section{INTRODUCTION}

The deep-sea is the lar gest biome on ear th. The seafloor at depths $>1000 \mathrm{~m}$ constitutes $\sim 65 \%$ of the earth's surface, hosting a collection of ecosystems with communities that ar e still lar gely unknown (Ramirez-Llodra et al. 2010, Snelgr ove 2010). Com- piling an adequate understanding of deep-sea animals' life habits such as distribution, diet, behaviour or r eproduction, has been hamper ed by technical difficulties in sampling at extr eme depths (Gage \& Bett 2005). As a $r$ esult, there is a major gap in knowledge on deep-sea ecosystems (Aguzzi et al. 2012). 
In the deep sea beyond the $\mathrm{r}$ each of sunlight ( $\mathrm{r}$ eviewed by Childress 1995) there are 2 major sources of energy provision: (1) autochthonous, derived from chemosynthetic communities, found e.g. at cold seeps or hydrothermal vents (Paull et al. 1985, Lutz \& Kennish 1993, Fujikura et al. 1999); and (2) allochthonous, delivered as particulate organic matter originating from the sur face waters or lar ge food falls (carrion carcasses; Stockton \& DeLaca 1982, Britton \& Morton 1994, Bailey et al. 2007). An undeter mined fraction of food supply is consumed by scavengers which feed upon dead biota, the sinking carcasses of which reach the seafloor with high ener gy contents (Klages et al. 2001). Car rion food falls may consistently support populations of scavengers from coastal environments to hadal depths (Jamieson et al. 2009a,b). Generally, a succession of bait-attending fauna appears rapidly at food falls. $T$ ypically, the dominant species are amphipods and demersal fish (Collins et al. 1999, Jones et al. 2003, Y eh \& Drazen 2009, Jamieson et al. 2011a, Y eh \& Drazen 2011). Amphipods are highly ef ficient in $\mathrm{r}$ emoving the external tissues of car rion falls, exposing the underlying mass, where fishes usually begin their feeding (Jones et al. 1998, Kemp et al. 2006, Jamieson et al. 2010, 2011b).

These observations are generally based on simulated carrion falls when bait is deliver ed to seafloor on landers (Bagley et al. 2004), or by Remotely Operated Vehicles (ROV; Humphris 2009). Natural food falls are extremely rarely observed with these in situ imaging-technologies as they ar e infrequent and unpredictable in space and time, making the pr obability of their detection extraordinarily low (Klages et al. 2001, Soltwedel et al. 2003, Yamamoto et al. 2009). However, the incr easing number of per manent video-observatories on the deep seafloor is providing new possibilities of ecological monitoring at longer timescales than ever befor e (Aguzzi et al. 2010, 2011a,b, 2012, Matabos et al. 2011, Ruhl et al. 2011).

We document an extraor dinary rare event which was recorded by a video system installed on a deepsea cabled video-obser vatory: a dying fish, while still alive, was intercepted by the scavenging gastropod Buccinum yoroianum Ozaki, 1958 (Neogasteropoda: Buccinidae; synonym: Buccinum soyomaruae Okutani, 1977). In or der to provide an over view of the feeding behaviour of buccinids and their eco logical relevance within deep-sea tr ophic food webs, we $r$ eport on supplementar y observations from a different area of the Pacific Ocean (the Per uChile Trench) using a baited camera lander to simulate food falls.

\section{MATERIALS AND METHODS}

\section{Cabled observatory video-annotations (natural food fall)}

The video ascer taining the natural food fall (an unknown macrourid fish) was captur ed by an in frared Panasonic CAM-92, 3CCD camera, mounted on the Real-T ime Deep-Sea Floor Per manent Observatory of Sagami Bay . The obser vatory is located in a hydr ocarbon cold seep field of clams (Calyptogena soyoae Okutani, 1957) at a depth of $1100 \mathrm{~m}$, of $\mathrm{f}$ the Hatsushima Island, central Japan (NW Pacific Ocean; 3459.97'N, 139¹3.69'E; Kasaya et al. 2009, Momma et al. 1998). The video spans $12 \mathrm{~h}(17: 00$ to 5:00 h, 24 June 1999), star ting $1 \mathrm{~h}$ prior to the fish falling and ending a few hours after. The camera $r$ ecorded in a time-lapse mode (1 frame every $5 \mathrm{~s}$ ), illuminated by a per manent source of white light, which does not perturb natural behaviour (Aguzzi et al. 2010b). The video film can be viewed at www.int-res.com/articles/suppl/ m458p247_supp/.

A 4-quadrant grid was superimposed on each frame in or der to precisely count gastropods within the different portions of the camera' s field of view (FOV). Only lar ge gastropods were counted whose body was fully included in 1 of the 4 quadrants. The temporal development of the scavenging activity was described by representing the sum of individuals per minute for each quadrant and for all quadrants together.

\section{Lander observations (simulated food falls)}

Buccinidae in the Per u-Chile Trench were observed using the Hadal-Lander B (Jamieson et al. 2009c). Between 1 and 5 September 2010, the lander was deployed in the tr ench at 6 dif ferent depths: $1037,4602,5329,6173,7050$ and $8074 \mathrm{~m}$. The lander recorded 5-megapixel digital still images (1 $\mathrm{min}^{-1}$ ) at an elevation of $1 \mathrm{~m}$ above seafloor. The FOV was $62 \times 46.5 \mathrm{~cm}\left(0.29 \mathrm{~m}^{-2}\right)$ and baited with $\sim 1 \mathrm{~kg}$ tuna (Thunnus spp.). To recover samples of photographed species for taxonomic identification, the 3 lander legs were fitted with small invertebrate funnel traps, also baited with tuna $(\sim 200 \mathrm{~g})$. The traps were positioned to rest directly on the seafloor when in situ.

In the acquir ed images, the shell lengths wer e measured using proprietary image analysis software Image J (NIH, USA), calibrated against a scale bar present in the FOV . Likewise, Image $\mathrm{J}$ was used to 
mark the position of individuals in subsequent images using the X-Y tool. The distance travelled between each image was then used to deter mine overground locomotion speed. The absolute speed $\left(\mathrm{cm} \mathrm{min}^{-1}\right)$ was divided by shell length (SL) to pr ovide a size-specific speed (SL $\left.\mathrm{min}^{-1}\right)$.

\section{RESULTS}

\section{Natural food fall event in Sagami Bay, Japan}

When the dying fish $\mathrm{r}$ eached the seafloor in the FOV at Min 58 (video start $t_{0}=17: 56 \mathrm{~h}$ ) the number of visible Buccinum yoroianum was low in all quadrants. The fish was still alive and visibly quivering for 75 min during the obser vation period. After the fish had reached the seafloor, the number of $B$. yoroianum increased from a minimum of 2 at Min 58 to a maximum of 76 at Min 205. They rapidly approached from the left upper quadrant and moved with their probosces protruded forward in an undulatory fashion. At the peak activity, 30 ind. (39\%) were on the carcass, $40(53 \%)$ remained in close pr oximity and only 6 (8\%) stayed away. By Min 482, the number of individuals had decreased to 2 . The carcass was completely consumed in $\sim 8 \mathrm{~h}$. The temporal $\mathrm{r}$ esponse of Buccinum yoroianum to the natural food fall is quantitatively described in Fig. 1.

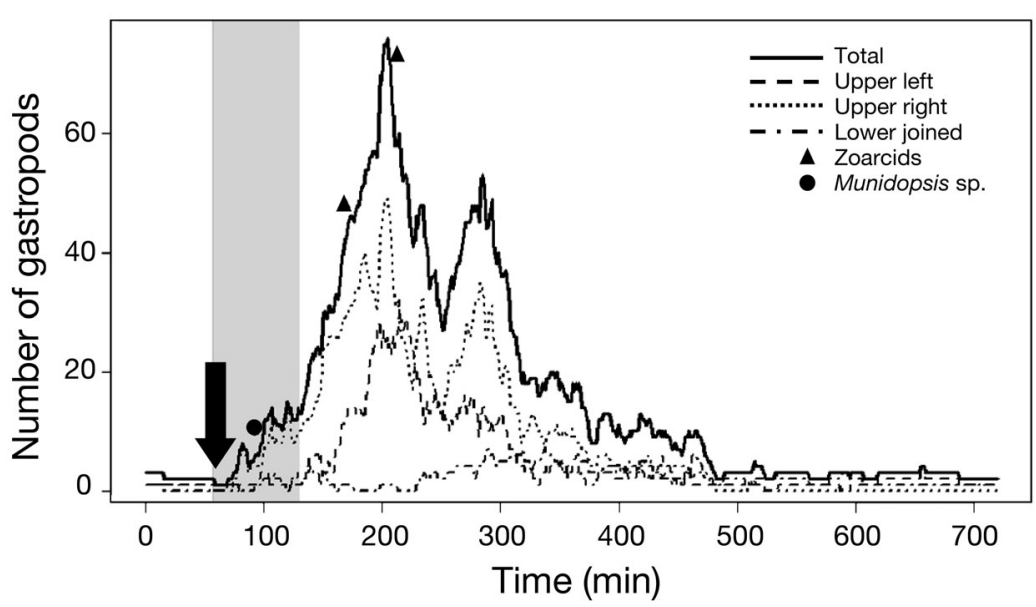

Fig. 1. Buccinum yoroianum. Time series of visual counts describing the mixed predatory-scavenging behaviour of this buccinid in Sagami Bay , Japan. Individuals were counted separately in the 4 quadrants of the camera's field of view, but counts from the lower quadrants were pooled. Numbers are presented along with the total. After fish -seabed contact (Min 75; arrow), the fish remained moribund for $75 \mathrm{~min}$ (shaded area). The number of gastropods increased rapidly, as individuals wer e probably attracted by the movements of the fish. The interaction of 2 zoar cids and 1 Munidopsis sp. is indicated
Buccinum yoroianum in the upper right quadrant also seemed to perceive the arrival of the fish and its twitching movements. However, their ability to locate the exact position of the fish was appar ently delayed in comparison to the individuals appr oaching from the opposite side, pr esumably as they wer e located upstream in the cur rent flow. The movements of the dying fish produced sediment plumes, which drifted in the ambient current leftward relative to the FOV.

Other species par ticipating in this scavenging event appeared only occasionally (see Fig. 1). A white squat lobster (Munidopsis sp.) was present for a very short time, without appr oaching the carcass. Zoarcid fishes interacted twice in this event at Min 173 and 207. The zoar cids were observed removing strips of tissue by twisting and $r$ otating their body. The first zoar cid was present in close pr oximity for 9 min while the second and smaller individual was sighted for only 2 min. Drifting sediment, $r$ esuspended by the first zoarcid feeding event at Min 173, confirmed the previously described dir ection of the currents.

\section{Simulated food fall event in the Peru-Chile Trench}

The buccinid Tacita zenkevitchi Lus, 1975 was observed at 2 sites in the Penu-Chile Trench $\left(4^{\circ} 27.016^{\prime} \mathrm{S}\right.$, $81^{\circ} 54.719^{\prime} \mathrm{W}, 5329 \mathrm{~m}$ deep; and $7^{\circ} \quad 48.042^{\prime} \mathrm{S}$, $81^{\circ} 17.011^{\prime} \mathrm{W}, 6173 \mathrm{~m}$ deep) over periods of $11 \mathrm{~h} 9 \mathrm{~min}$ and $18 \mathrm{~h} 40 \mathrm{~min}$, respectively (Fig. 2). At $5329 \mathrm{~m}, 6 \mathrm{~h}$ 3 min after the lander touchdown, individuals aggregated on the bait, increasing to a maximum of 5 individuals just prior the end of recording (9 h, $46 \mathrm{~min}$; Fig. 3). Each gastr opod entered the FOV, travelled dir ectly to the bait and positioned itsself on top of it. There they stayed until being for cibly removed by a macrourid fish Coryphaenoides yaquinae. At $6173 \mathrm{~m}$, the buccinid be haviour appeared similar to that at $5329 \mathrm{~m}$ in the early stages (Fig. 3), but then was incr easingly disturbed by an unidentified ophidiid fish: some gastropods were repeatedly knocked over, driven into the sediment, or $\mathrm{r}$ emoved from the FOV.

At $5329 \mathrm{~m}$, Tacita zenkevitchi individuals had a SL of $5.33 \pm 0.7$ (mean \pm SD), and $4.7 \pm 1.1 \mathrm{~cm}$ at $6173 \mathrm{~m}$. Fr om the baited traps at $6173 \mathrm{~m}, 3$ specimens 

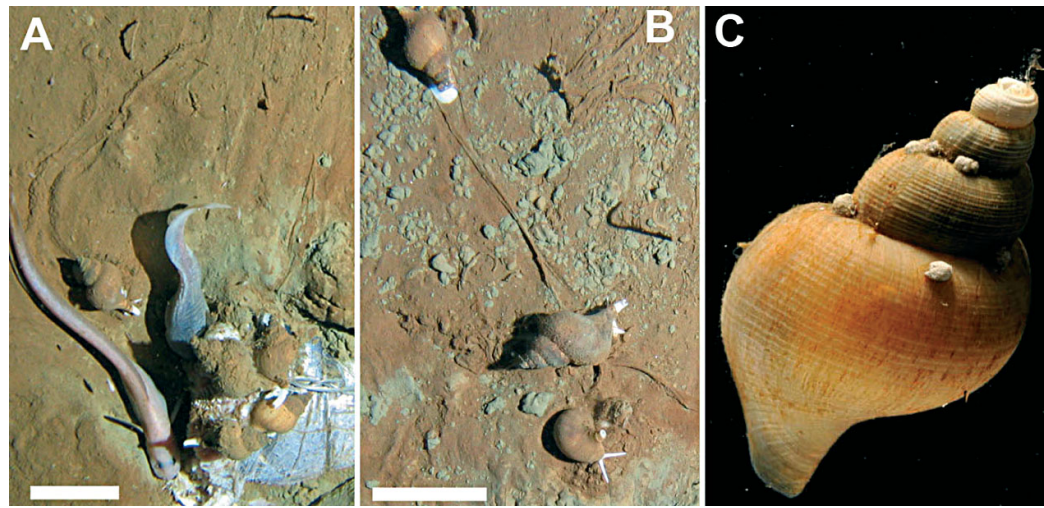

Fig. 2. Tacita zenkevitchi. Aggregation individuals at $5329 \mathrm{~m}$ depth in the Peru-Chile Trench. (A) Four individuals ar e sitting on the bait, a fifth is approaching (between the zoarcid and liparid fishes). (B) Mucus trail left in the gastropod's track. (C) T. zenkevitchi recovered from the baited trap at $6173 \mathrm{~m}$ (shell height $=45 \mathrm{~mm}$ ). Scale bar in A and B: $5 \mathrm{~cm}$

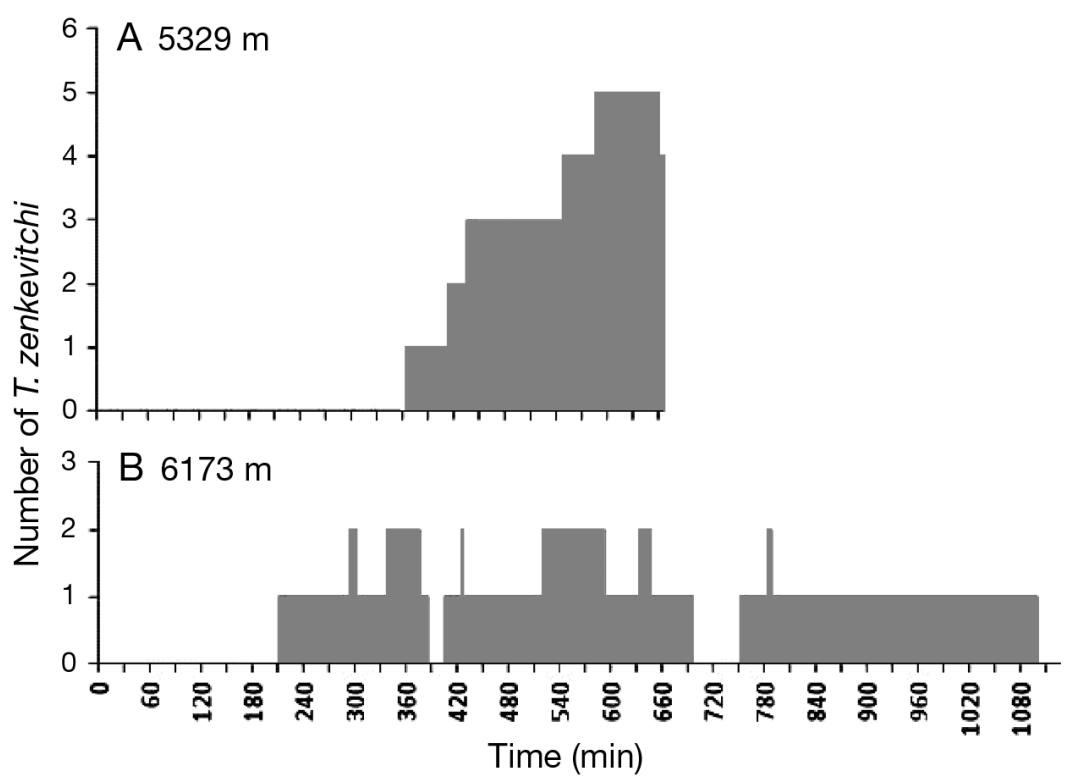

Fig. 3. Tacita zenkevitchi. The ar rival rate of individuals at the bait at (A) $5329 \mathrm{~m}$ depth, showing a linear incr ease in numbers over time $(y=0.0144 x-$ 4.1729; $\mathrm{R}^{2}=0.89$ ) until the end of pictur e-taking, and at (B) $6173 \mathrm{~m}$ depth, where the arrival rate is perturbed by an unidentified ophidiid fish were recovered (see Table 1 for morphometric data), while none wer e recovered from $5329 \mathrm{~m}$.

Tacita zenkevitchi travelled towards the bait at an absolute speed of $3.2 \pm$ $1.5 \mathrm{~cm} \mathrm{~min}^{-1}$ (mean $\pm \mathrm{SD}$; specific speed $=0.6 \pm 0.3 \mathrm{SL} \mathrm{min}^{-1}$ ) at $5329 \mathrm{~m}$, and $2.3 \pm 1.2 \mathrm{~cm} \mathrm{~min}^{-1}(0.6 \pm 0.2 \mathrm{SL}$ $\mathrm{min}^{-1}$ ) at $6173 \mathrm{~m}$. T. zenkevitchi left clearly visible tracks of depr essed sediment with a mucus lining. This lining was ob served to peel of $f$ the seafloor when another individual traversed through it. The width of the tracks was $1.7 \pm 0.3 \mathrm{~cm}$. $\mathrm{T}$ ogether with the mean locomotion speed of $T$. zenkevitchi this results in an average area coverage of $0.03 \pm 0.02 \mathrm{~m}^{-2} \mathrm{~h}^{-1}$ per individual.

\section{DISCUSSION}

We observed how Buccinum yoroianum rapidly aggregated on and consumed a naturally moribund fish in the cold seep clam field of Sagami Bay while the dying fish was still moving. Thus, the buccinids r evealed a mixed predatory and scavenging feeding activity. We also reported on the pur ely scavenging behaviour of another buccinid species, Tacita zenkevitchi, from a different oceanic ar ea, the Per uChile Trench. These observations can be ecologically generalized to confirm the opportunistic mixed predatory and scavenging behavioural guild for deep-sea buccinids. This is the first time that a natural food fall has been witnessed in the deep sea both prior to, and after, an animal has actually died (Yamamoto et al. 2009).

Our findings fr om simulated food-fall experiments with a lander wer e also surprising. Fr om previous baited camera literatur e (Jones et al. 1998, 2003, Jamieson et al. 2009c, 2011a), it ap pears that buccinid gastropods were only mar ginally detected and their ecological $r$ ole in food-fall consumption was appar ently negligible. Landers similar to the one used in the pr esent study have been used hundr eds of times at many depths in many geographic locations and gastr opods were
Table 1. Tacita zenkevitchi. Morphometric data from 3 specimens of the buccinid gastr opod recovered from $6173 \mathrm{~m}$ in the Peru-Chile Trench

\begin{tabular}{|lccccc|}
\hline \multirow{2}{*}{ Specimen } & \multicolumn{2}{c}{ Shell $(\mathrm{mm})$} & \multicolumn{2}{c|}{ Aperture $(\mathrm{mm})$} & No. of \\
& Height & Width & Height & Width & whorls \\
\hline 1 & 45 & 26 & 25 & 15 & 4 \\
2 & 23 & 13 & 13 & 7 & 4 \\
3 & 25 & 13 & 14 & 9 & 4 \\
\hline
\end{tabular}


seldom reported. The presence of buccinids in the Peru-Chile Trench and in Sagami Bay can possibly be explained by the chemosynthetic typology of the surveyed habitats. The Per u-Chile Trench is a seismically active subduction zone with associated hydrothermal vents and cold seeps ( $\mathrm{T}$ orres et al. 1996, Fujikura et al. 1999). W e hypothesize that the increased presence of Buccinidae at these sites and not in the wider deep sea, may be an ef fect of these geological featur es, in the pr oximity of which gastropods are known to aggr egate (Warèn \& Bouchet 1993, Bates et al. 2005).

Although foraging methods of deep-sea scavengers are still somewhat speculative, odour plume detection within downstream currents may occur by actively searching (Rochette et al. 1994) or by a sitand-wait strategy (Bailey \& Priede 2002). In Sagami Bay, buccinids rapidly located the dying fish within the ambient cur rent regime which, however, could not be quantified in the absence of current meters at the observatory. Nevertheless, the dir ection of the current was inferred indirectly by video inspection of resuspended sediment. The appr oach to the event from down cur rent suggests that buccinids utilize their olfactory senses to detect prey or carrion odours carried by currents. The detection of noise associated with carrion falls $\mathrm{r}$ eaching the seabed as well as the associated noise and vibrations of scavenging activity may contribute to locating a food fall via mechanoreception (Klages et al. 2002, Pr emke et al. 2003).

Although zoarcids and galatheid squat lobsters were occasionally present, the over whelming dominance of the buccinid gastropods and absence of any large scavenging fish was surprising in the Sagami Bay observations. The reason for the absence of other major fauna is presently unknown as no other studies of this kind have focused on the behaviour of macrofauna in the Sagami Bay cold seep ar ea. Unexpectedly, no r ed crabs Paralomis multispina were observed despite this species' known abundance in the area (Aguzzi et al. 2010b). Also, only a single white galatheid species (Munidopsis sp.; Cubelio et al. 2008), known to be endemic in cold seep ar eas including Sagami Bay, was obser ved. Most baited camera studies indicate a prominent role of scavenging amphipods (e.g. Hessler et al. 1978, Blankenship \& Levin 2007, Jamieson et al. 2009b). However, their role in the por trayed scavenging event could not be assessed due to the relatively large distance from the camera to the car cass and the low $r$ esolution of the video system, pr obably insufficient to detect such small organisms. Scavenging amphipods are likely the dominant gr oup in Sagami, making buccinids only the second most impor tant one (Nishida et al. 1999). The absence of scavenging fishes was also conspicuous, as they ar e dominant at similar depths in other locations (e.g. King et al. 2006, 2008, Y eh \& Drazen 2009, 2011).

Deep-sea Buccinidae may include species with an obligate scavenging life-style (Britton \&Morton 1994, Martell et al. 2002, Ilano et al. 2005). Never theless, the unpredictable source of food in the form of sparse carrion falls suggests taxa are unlikely to favour such a specialization towards obligate scavenging (Kaiser \& Moore 1999). According to our observations, buccinids can be broadly considered as both opportunistic scavengers and predators (Nickell \& Moore 1992, Naganuma et al. 1996).

The speed at which buccinids can traverse the seafloor is also impor tant in terms of bioturbation of surface sediments. The $\mathrm{r}$ esults from the Per u-Chile Trench showed a (size-specific) locomotion speed of $0.6 \mathrm{SL} \mathrm{min}^{-1}$ and a track width of $1.7 \mathrm{~cm}$. This pr ovided an ar ea of coverage (mean $\pm \mathrm{SD}$ ) of $0.03 \pm$ $0.02 \mathrm{~m}^{2} \mathrm{~h}^{-1}$ per gastropod. Assuming the size and speed of the Sagami Bay population is similar, then just 33 of these individuals would have coveed $\sim 1 \mathrm{~m}^{2}$ of seafloor in $1 \mathrm{~h}$. Therefore the mass aggregations of facultative scavenging gastropods is not only important to the dispersal of sur face-derived organic matter in the form of food falls, but also to rapid bioturbation within the vicinity of the food fall and in the wider catchment area of the odour plume.

In conclusion, our perception of deep-sea buccinid feeding habits seems to be conditioned by our sampling method. They appear as scavengers when using baited cameras, and conversely as pr edators, when using prolonged video r ecording as by fixed cameras in cabled video-observatories.

Acknowledgements. We thank Dr. R. Iwase from the Japan Agency Marine-Earth Science and Technology (JAMSTEC) for his assistance with video material. Dr . J.B. Company, Marine Science Institute (ICM-CSIC), is acknowledged for his commentaries and help during the pr eparation of this manuscript. We thank Dr. N. Kilgallen (NIW A, New Zea land) and Dr. K. Kitazawa (AORI, Japan) for their assistance at sea and the captain and cr ew of the R V 'Sonne' cr uise SO209 and RV 'Hakuho-Maru' KH-08-03. We also thank Dr. B. Marshall at the Museum of New Zealand 'T e Papa Tongarewa' (Wellington) for indentifying the lander specimens. The lander work and A.J.J. wer e supported by the Nippon Foundation (Japan) and the Marine Alliance for Science and Technology, Scotland (MASTS). Sagami video material was retrieved and analyzed in the context of the RITFIM Pr oject (CTM2010-16274), funded by the Spanish Ministr y for Science and Innovation (MICINN). J. Aguzzi is a Ramón y Cajal Program (MICINN) Postdoctoral Fellow. 


\section{LITERATURE CITED}

Aguzzi J, Costa C, Furushima Y, Chiesa JJ and others (2010) Behavioural rhythms of hydrocarbon seep fauna in relation to internal tides. Mar Ecol Prog Ser 418:47-56

Aguzzi J, Company JB, Costa C, Menesatti P, Bahamon N, Sardà F (2011a) Activity rhythms in the deep-sea cr ustacean: chronobiological challenges and potential technological scenarios. Front Biosci 16:131-150

Aguzzi J, Costa C, Robert K, Matabos M, Antonucci F, Juniper K, Menesatti P (2011b) Automated video-imaging for the detection of benthic crustaceans and bacterial mat coverage at VENUS cabled network. Sensors (Basel) 11:10534-10556

Aguzzi J, Company JB, Costa C, Matabos M and others (2012) Biorhythms challenge to stock and biodiversity assessments: cabled obser vatories video-solutions. Oceanogr Mar Biol Annu Rev 50:233-284

Bagley PM, Priede IG, Jamieson AJ, Bailey DM, Battle EJV, Henriques C, Kemp KM (2004) Lander techniques for deep ocean biological $r$ esearch. Underwat Technol 26: 3-11

Bailey DM, Priede IG (2002) Predicting fish behaviour in response to abyssal food-falls. Mar Biol 141:831-840

> Bailey DM, King NJ, Priede IG (2007) Camera and car casses: historical and current methods for using artificial food falls to study deep-water animals.Mar Ecol Prog Ser 350:179-191

Bates AE, Tunnicliffe V, Lee RW (2005) Role of thermal conditions in habitat selection by hydr othermal vent gastropods. Mar Ecol Prog Ser 305:1-15

Blankenship LE, Levin LA (2007) Extreme food webs: foraging strategies and diets of scavenging amphipods from the ocean's deepest 5 kilometers. Limnol Oceanogr 52:1685-1697

Britton JC, Morton B (1994) Marine carrion and scavengers. Oceanogr Mar Biol Annu Rev 32:369-434

Childress JJ (1995) Do animals present biochemical adaptations to depths? Trends Ecol Evol 10:30-36

> Collins MA, Priede IG, Bagley P (1999) In situ comparison of activity of two deep-sea scavenging fishes occupying different depth zones. Proc Biol Sci 266:2011-2016

Cubelio SS, Tsuchida S, Watanabe S (2008) New species of Munidopsis (Decapoda: Anomura: Galatheidae) fr om hydro thermal vent in Okinawa Trough and cold seep in Sagami Bay. Crust Res 36:1-14

Fujikura K, Kojima S, Tamaki K, Maki Y, Hunt J, Okutani T (1999) The deepest chemosynthesis-based community yet discovered from the hadal zone, $7326 \mathrm{~m}$ deep, in the Japan Trench. Mar Ecol Prog Ser 190:17-26

Gage JD, Bett BJ (2005) Deep-sea benthic sampling. In: Eleftheriou A, McIntyre AD (eds) Methods for the study of the marine benthos, 3r d Edition, Blackwell, Oxfor d, p 273-325

Hessler RR, Ingram CL, Yayanos AA, Burnett BR (1978) Scavenging amphipods from the floor of the Philippine Trench. Deep-Sea Res I 25:1029-1047

Humphris SE (2009) Vehicles for deep sea exploration. In: Steele JH, Turekian KK, Thorpe SA (eds) Encyclopaedia of ocean science, 2nd edn. Elsevier , Amsterdam, p 4647-4659

> Jamieson AJ, Fujii T, Solan M, Matsumoto AK, Bagley PM, Priede IG (2009a) First findings of decapod cr ustacea in the hadal-zone. Deep-Sea Res I 56:641-647

Jamieson AJ, Fujii T, Solan M, Matsumoto AK, Bagley PM,
Priede IG (2009b) Liparid and macr ourid fishes of the hadal zone: in situ observations of activity and feeding behavior. Proc Biol Sci 276:1037-1045

Jamieson AJ, Fujii T, Solan M, Priede IG (2009c) HADEEP: Free-falling landers to the deepest places on Ear th. Mar Technol Soc J 43:151-159

Jamieson AJ, Fujii T, Mayor DJ, Solan M, Priede IG (2010) Hadal trenches: the ecology of the deepest places on Earth. Trends Ecol Evol 25:190-197

> Jamieson AJ, Kilgallen NM, Rowden AA, Fujii T and others (2011a) Bait-attending fauna of the Kar madec Trench, SW Pacific Ocean: evidence for an ecotone acr oss the abyssal-hadal transition zone. Deep-Sea Res I 58:49-62

> Jamieson AJ, Fujii T, Bagley PM, Priede IG (2011b) Scavenging interactions between the ar row tooth eel Synaphobranchus kaupii and the Portuguese dogfish Centroscymus coleolepis. J Fish Biol 79:205-216

> Jones EG, Collins MA, Bagley PM, Addison S, Priede IG (1998) The fate of cetacean car casses in the deep sea: observations on consumption rates and succession of scavenging species in the abyssal nor th-east Atlantic Ocean. Proc Biol Sci 265:1119-1127

> Jones EG, Tselepides A, Bagley PM, Collins MA, Priede IG (2003) Bathymetric distribution of some benthic and benthopelagic species attracted to baited cameras and traps in the deep easter $n$ Mediterranean. Mar Ecol Prog Ser 251:75-86

> Kaiser MJ, Moore PG (1999) Obligate marine scavengers: do they exist? J Nat Hist 33:475-481

> Kasaya T, Mitsuzawa K, Goto TN, Iwase R and others (2009) Trial of multidisciplinary observation at an expandable sub-marine cabled Station 'off-Hatsushima Island Observatory' in Sagami Bay , Japan. Sensors (Basel) 9:92419254

> Kemp KM, Jamieson AJ, Bagley PM, McGrath H, Bailey DM, Collins MA, Priede IG (2006) Consumption of a large bathyal food fall, a six month study in the nor theast Atlantic. Mar Ecol Prog Ser 310:65-76

King NJ, Bagley PM, Priede IG (2006) Depth zonation and latitudinal distribution of deep-sea scavenging demersal fishes of the Mid-Atlantic Ridge, 42 to $53^{\circ}$ N. Mar Ecol Prog Ser 319:263-274

King NJ, Jamieson AJ, Bagley PM, Priede IG (2008) Deepsea scavenging demersal fish fauna of the Nazaré Canyon system, Iberian coast, north-east Atlantic Ocean. J Fish Biol 72:1804-1814

Klages M, Vopel K, Bluhm H, Brey T, Soltwedel T, Arntz WE (2001) Deep-sea food falls: first observations of a natural event in the Arctic Ocean. Polar Biol 24:292-295

> Klages M, Muyakshin S, Solwedel T, Arntz WE (2002) Mechanoreception, a possible mechanism for food fall detection in deep-sea scavengers. Deep-Sea Res I 49: 143-155

Lutz RA, Kennish MJ (1993) Ecology of deep-sea hydr othermal vent communities: a r eview. Rev Geophys 31: 211-242

> Matabos M, Aguzzi J, Robert K, Costa C, Menesatti P, Company JB, Juniper SK (2011) Multi-parametric study of behavioural modulation in demersal decapods at the VENUS cabled obser vatory in Saanich Inlet, British Columbia, Canada. J Exp Mar Biol Ecol 401:89-96

Momma H, Iwase R, Mitsuzawa K, Kaiho Y, Fujiwara Y (1998) Preliminary results of a thr ee-year continuous observation by a deep seafloor obser vatory in Sagami Bay, central Japan. Phys Earth Planet Inter 108:263-274 
Naganuma T, Wada H, Fujioka K (1996) Biological com munity and sediment fatty acids associated with the deep-sea whale skeleton at the $\mathrm{T}$ orishima Seamount. J Oceanogr 52:1-15

Nickell TD, Moore PG (1992) The behavioural ecology of epibenthic scavenging inver tebrates in the Clyde Sea area: laboratory experiments on attractions to bait in moving water, underwater TV observation in situ and general conclusions. J Exp Mar Biol Ecol 159:15-35

Nishida S, Kikuchi T, Toda T (1999) Efficient capture of deep-sea hyperbenthic calanoid copepods with baited traps. Plankton Biol Ecol 46:165-168

Paull CK, Jull AJT, Toolin LJ, Limick T (1985) Stable isotope evidence for chemosynthesis in an abyssal seep community. Nature 317:709-711

Premke K, Muyakshin S, Klages M, Wegner J (2003) Evidence for long range chemor eceptive tracking of food odour in deep sea scavengers by scanning sonar data. J Exp Mar Biol Ecol 285-286:283-294

Ramsay K, Kaiser MJ, Hughes RN (1998) Responses of benthic scavengers to fishing disturbance by towed gears in different habitats. J Exp Mar Biol Ecol 224:73-89

Rochette R, Hamel JF, Himmelman JH (1994) Foraging strategy of the aster oid Leptasterias polaris: role of pr ey odours, current and feeding status. Mar Ecol Prog Ser 106:93-100

Ruhl HA, André M, Beranzoli L, Çağatay MN and others (2011) Societal need for impr oved understanding of cli-

Editorial responsibility: Paul Snelgrove, St. John's, Newfoundland and Labrador, Canada mate change, anthr opogenic impacts, and geo-hazar d warning drive development of ocean obser vatories in European Seas. Prog Oceanogr 91:1-33

Snelgrove PVR (2010) Discoveries of the Census of marine life: making ocean life count. Cambridge University Press, UK

> Soltwedel T, von Juterzenka K, Premke K, Klages M (2003) What a lucky shot! Photographic evidence for a mediumsized natural food-fall at the deep-seafloor. Oceanol Acta 26:623-628

Stockton WL, DeLaca TE (1982) Food falls in the deep sea: Occurrence, quality, and significance. Deep-Sea Res I 29:157-169

Torres ME, Bohrmann G, Suess E (1996) Authigenic barites and fluxes of barium associated with fluid seeps in the Peru subduction zone. Earth Planet Sci Lett 144:469-481

> Warèn A, Bouchet P (1993) New r ecords, species, genera, and a new family of gastropods from hydrothermal vents and hydrocarbon seeps. Zool Scr 22:1-90

> Yamamoto J, Nobetsu T, Iwamori T, Sakurai Y (2009) Observation of food falls at the Shir etoko Peninsula, Japan, using remotely operated vehicle. Fish Sci 75:513-515

Yeh J, Drazen JC (2009) Depth zonation and bathymetric trends of deep-sea megafaunal scavengers of the Hawaiian Islands. Deep-Sea Res I 56:251-266

Yeh J, Drazen JC (2011) Baited-camera obser vations of deep-sea megafaunal scavenger ecology on the Califor nia slope. Mar Ecol Prog Ser 424:145-156

Submitted: January 25, 2012; Accepted: April 13, 2012

Proofs received from author(s): June 15, 2012 